\title{
Preparedness and willingness of dental care providers to treat patients with special needs
}

This article was published in the following Dove Press journal:

Clinical, Cosmetic and Investigational Dentistry

\section{Arwa Alumran \\ Luloah Almulhim \\ Bainah Almolhim \\ Shouq Bakodah \\ Hessa Aldossary \\ Zahra Alakrawi}

Health Information Management and Technology Department, College of Public Health, Imam Abdulrahman Bin Faisal University, Dammam, Saudi Arabia
Correspondence: Arwa Alumran Health Information Management and Technology Department, College of Public Health, Imam Abdulrahman Bin Faisal University, PO Box 40I40, Alkhobar 31952, Saudi Arabia

Tel +966506845783

Email aalumran@iau.edu.sa

\begin{abstract}
This study aimed to review the available literature about special needs dentistry, factors affecting treatment of patients with special needs, dental education, and the preparedness and willingness of dental care providers to treat patients with special needs. The study also aimed to assess the validity and reliability of available scales that measure the preparedness of dental care providers to treat patients with special needs. Forty studies from esteemed refereed journals were reviewed in this article. The topics in the study were relevant to special needs dentistry, Saudi Arabia, and dental care providers' perceptions of treating patients with special needs. Reviewed studies were extracted from several electronic databases, such as PubMed and Medline. Studies in Saudi Arabia about special needs dentistry and the preparedness of dental care providers to treat patients with special needs are scarce. Further research in this area needs to be conducted in Saudi Arabia.
\end{abstract}

Keywords: oral health, dental education, quality of healthcare, social determinants of health

\section{Introduction}

As reported by the United Nations, more than half of a billion people worldwide experience disabilities due to mental, physical, or sensory impairment. ${ }^{1}$ According to the American Dental Association (2017), people with disabilities - special needs often require "special consideration when receiving dental treatments because of their developmental or cognitive conditions". This can also include patients with Autism spectrum disorder, Alzheimer's disease, Down syndrome, or any conditions that make dental procedures more difficult. ${ }^{2}$

In fact, this complexity in treating patients with special needs had led to the evolution of special care dentistry. In the USA, special needs dentistry is defined as "a method of oral health management that is specially designed for patients with special needs who have a variety of medical conditions or disabilities that require more time or altered delivery methods than the routine delivery of dental care for the general population." ${ }^{2}$ Also, special needs dentistry is defined by the Royal Australasian College of Dental Surgeons as a type of dentistry that focuses attention on oral health care for disabled patients who required special methods and techniques to treat their oral health conditions. ${ }^{3}$ According to Gallagher and Fiske, ${ }^{4,5}$ special care dentistry extends beyond health management to the improvement of oral health outcomes in patients with special needs who often have a combination of different disabling conditions.

Despite this remarkable progress in medicine and dentistry, studies have shown that individuals with special health care needs have more risk of developing dental 
problems and untreated dental diseases compared with their healthier counterparts. ${ }^{5,6}$ In addition to the poorer oral health outcomes, patients with special needs are more likely to have limited access to dental care services, which can contribute to a major health disparity between people with special needs and the general population.

In fact, the lack of willingness and the competence of dental care providers to treat patients with special health care needs, as well as the hurdles these providers face themselves, remain barriers to provide access to dental care. ${ }^{6,7}$ Thus, dental care providers should be better educated, trained, and prepared to effectively manage patients with special needs in an effort to minimize oral health disparities within this population. Furthermore, all patients with special needs must have equal access and high-quality treatment that focuses on patient safety, patient-centered care, and treatment of all dental needs.

In Saudi Arabia alone, there are approximately one million individuals with a disability, ${ }^{5}$ which represents a pressing demand for special needs dentistry to be further explored on a national level. This study lays the foundation for understanding the factors that influence access to dental health services by people with special needs through a review of the literature concerning dental care providers' perceptions of treating this population of patients.

The Iron Triangle of Health Care $^{8}$ framework has been used to guide this literature review, where this framework suggests that health care relies on the following three major aspects: access, quality, and cost. An increase or a decrease in one aspect will have an effect on the other aspects someway.

\section{Methodology}

Studies about dental care providers and patients with special needs were reviewed from several electronic databases, such as PubMed and Medline. A total of 40 studies were reviewed from different countries around the world, including the USA, Malaysia, Taiwan, ROC, and Saudi Arabia. From the reviewed studies, 16 scales that measure the preparedness and willingness of dental care providers were assessed for their reliability and validity (Table 1 ).

\section{Literature review Access to health care}

Various studies have indicated that individuals with special needs have limited access to dental clinics for many reasons, including their physical or mental disabilities. ${ }^{6}$ Their ability to physically access the dental clinics and offices, along with their ability to afford the cost of the treatment and inadequate financing for dental treatment, may hinder their access to den- tal clinics. ${ }^{6,9-12}$ Moreover, the preparedness and willingness of dental care providers to treat patients with special needs may impact access and thus their oral health. ${ }^{1,3,13}$

One of the studies that investigated dentists' knowledge and attitudes toward treating patients with special needs found that majority of the studied dentists reported having difficulty treating such patients. The study also highlighted those dentists did not have training or special education to handle this type of patients. ${ }^{14}$ Another study that was conducted in Poland in 2014 assessed the access of special needs schoolchildren to dental care services based on parents' perception and found that the level of intellectual disability can play a role in the accessibility of individuals with special needs to dental care services. In that study, parents with children with mild disability reported facing fewer barriers to access dental health care. This was contrary to the parents of children with severe disability, who reported encountering more access problems. This can indicate the degree to which the level of training and education of dentists can influence the access to dental care services of patients with special needs, who will have different levels of disability. ${ }^{15}$

The lack of preparedness of dentists to treat patients with special needs can influence their degree of willingness to treat those patients. However, this is not always the case since sometimes dentists are willing to treat patients with special needs to help reduce the inequality in accessing dental health care services. Nonetheless, their willingness to treat special needs patients is hampered by their perceived level of preparedness to provide dental services to this population. ${ }^{10,14}$

\section{Quality of care}

\section{Dental education}

Attempts to promote the education of undergraduate dental students with regard to treating patients with special needs and making them more prepared date back to the 1970 s, when Robert Wood Johnson provided large grants to 11 dental colleges in the USA to develop teaching programs for patients with special needs or disabling conditions. ${ }^{13,14}$ One study found that in Saudi Arabia, dentists who treat patients with special needs are dental pediatrics; there are no dental specialists to manage patients who are adults with special needs, and there are no structured dental programs or courses for undergraduate dental students. ${ }^{5}$ Lack of training and experience of undergraduate dental students in dealing with patients with special needs was one of the most reported issues that inhibits the treatment of these patients. ${ }^{3}$ Moreover, most dental educators are specialists in their field and have little or no interest in other dentistry fields. ${ }^{15}$ 
Table I Scale directed to dental care providers

\begin{tabular}{|c|c|c|c|c|c|c|}
\hline Study & Country & $\begin{array}{l}\text { Target } \\
\text { population }\end{array}$ & $\begin{array}{l}\text { Development } \\
\text { and validation of } \\
\text { instrument }\end{array}$ & Implementation & $\begin{array}{l}\text { Reliability of } \\
\text { instrument }\end{array}$ & $\begin{array}{l}\text { Dimensions } \\
\text { measured in the } \\
\text { scale }\end{array}$ \\
\hline $\begin{array}{l}\text { Holder, } \\
\text { Waldman, and } \\
\text { Hood, 2009' }\end{array}$ & USA & $\begin{array}{l}\text { Deans of dental/ } \\
\text { medical schools, } \\
\text { directors of } \\
\text { residency } \\
\text { programs, and } \\
\text { medical students }\end{array}$ & $\begin{array}{l}\text { Development and } \\
\text { validation were not } \\
\text { mentioned }\end{array}$ & $\begin{array}{l}\text { E-mailed } \\
\text { questionnaire }\end{array}$ & $\begin{array}{l}\text { Reliability was } \\
\text { not mentioned }\end{array}$ & $\begin{array}{l}\text { Perceptions of } \\
\text { preparation }\end{array}$ \\
\hline $\begin{array}{l}\text { Dao, } \\
\text { Zwetchkenbaum, } \\
\text { and Inglehart, } \\
2005^{13}\end{array}$ & USA & Dentists & $\begin{array}{l}\text { Development and } \\
\text { validation were not } \\
\text { mentioned }\end{array}$ & $\begin{array}{l}\text { Mailed } \\
\text { questionnaire }\end{array}$ & $\begin{array}{l}\text { Reliability was } \\
\text { not mentioned }\end{array}$ & Experience, attitudes \\
\hline $\begin{array}{l}\text { Clemetson et al, } \\
2012^{16}\end{array}$ & USA & Dentists & $\begin{array}{l}\text { Self-developed, } \\
\text { content and face } \\
\text { validity conducted }\end{array}$ & $\begin{array}{l}\text { Mailed } \\
\text { questionnaire }\end{array}$ & $\begin{array}{l}\text { Reliability was } \\
\text { not mentioned }\end{array}$ & $\begin{array}{l}\text { Infrastructure at } \\
\text { dental school, } \\
\text { availability of services, } \\
\text { and knowledge, and } \\
\text { compliance with } \\
\text { standards }\end{array}$ \\
\hline $\begin{array}{l}\text { Alkahtani et al, } \\
2014^{26}\end{array}$ & $\begin{array}{l}\text { Saudi Arabia } \\
\text { and USA }\end{array}$ & $\begin{array}{l}\text { Dental school } \\
\text { alumni }\end{array}$ & $\begin{array}{l}\text { Self-developed using } \\
\text { instruments from } \\
\text { the literature. Face } \\
\text { validity was done }\end{array}$ & $\begin{array}{l}\text { Web-based } \\
\text { questionnaire }\end{array}$ & $\begin{array}{l}\text { Retest } \\
\text { reliability }\end{array}$ & $\begin{array}{l}\text { Attitudes, knowledge, } \\
\text { and experience }\end{array}$ \\
\hline $\begin{array}{l}\text { Derbi and } \\
\text { Borromeo, } \\
2016^{30}\end{array}$ & Australia & Dentists & $\begin{array}{l}\text { Previously validated } \\
\text { survey }\end{array}$ & $\begin{array}{l}\text { Self-administered } \\
\text { questionnaire }\end{array}$ & $\begin{array}{l}\text { Reliability was } \\
\text { not mentioned }\end{array}$ & $\begin{array}{l}\text { Perception, } \\
\text { awareness of } \\
\text { government } \\
\text { programs, criteria for } \\
\text { referral, teaching and } \\
\text { training, consideration } \\
\text { of postgraduate } \\
\text { training }\end{array}$ \\
\hline $\begin{array}{l}\text { Casamassimo, } \\
\text { Seale, and Ruehs, } \\
2004^{31}\end{array}$ & USA & $\begin{array}{l}\text { General } \\
\text { practitioners } \\
\text { from the } \\
\text { American Dental } \\
\text { Association }\end{array}$ & Not mentioned & $\begin{array}{l}\text { Mailed } \\
\text { questionnaire }\end{array}$ & $\begin{array}{l}\text { Reliability was } \\
\text { not mentioned }\end{array}$ & $\begin{array}{l}\text { Experience, } \\
\text { and educational } \\
\text { preparation }\end{array}$ \\
\hline $\begin{array}{l}\text { Vainio, Krause, } \\
\text { and Inglehart, } \\
2013^{34}\end{array}$ & USA & $\begin{array}{l}\text { Deans at dental } \\
\text { schools and pre- } \\
\text { doctoral dental } \\
\text { students }\end{array}$ & $\begin{array}{l}\text { Self-developed using } \\
\text { instruments from the } \\
\text { literature. Content } \\
\text { and face validity was } \\
\text { done }\end{array}$ & $\begin{array}{l}\text { Web-based } \\
\text { questionnaire, and } \\
\text { paper based }\end{array}$ & $\begin{array}{l}\text { Reliability was } \\
\text { not mentioned }\end{array}$ & $\begin{array}{l}\text { Perceptions of } \\
\text { education, attitudes, } \\
\text { satisfaction, } \\
\text { confidence, and } \\
\text { future intentions }\end{array}$ \\
\hline $\begin{array}{l}\text { Ahmad, Razak, } \\
\text { and Borromeo, } \\
2014^{35}\end{array}$ & $\begin{array}{l}\text { Malaysia and } \\
\text { Australia }\end{array}$ & $\begin{array}{l}\text { The deans of } \\
\text { Malaysian and } \\
\text { Australian dental } \\
\text { schools }\end{array}$ & $\begin{array}{l}\text { Validated (type of } \\
\text { validation was not } \\
\text { mentioned) }\end{array}$ & $\begin{array}{l}\text { Postal } \\
\text { questionnaire }\end{array}$ & $\begin{array}{l}\text { Reliability was } \\
\text { not mentioned }\end{array}$ & $\begin{array}{l}\text { Education, and } \\
\text { perception of } \\
\text { education }\end{array}$ \\
\hline $\begin{array}{l}\text { Kleinert et al, } \\
2007^{36}\end{array}$ & USA & Dental students & $\begin{array}{l}\text { Development and } \\
\text { validation were not } \\
\text { mentioned }\end{array}$ & $\begin{array}{l}\text { Interactive, } \\
\text { multimedia, virtual } \\
\text { patient modules, } \\
\text { with pre- and post- } \\
\text { tests }\end{array}$ & $\begin{array}{l}\text { Reliability was } \\
\text { not mentioned }\end{array}$ & $\begin{array}{l}\text { The difficulty of } \\
\text { understanding Down } \\
\text { syndrome }\end{array}$ \\
\hline $\begin{array}{l}\text { DeLucia and } \\
\text { Davis, } 2009^{37}\end{array}$ & USA & Dental students & $\begin{array}{l}\text { Development was } \\
\text { not mentioned. } \\
\text { Construct validity } \\
\text { was done (inter-item } \\
\text { correlation) }\end{array}$ & $\begin{array}{l}\text { Self-administered } \\
\text { questionnaire }\end{array}$ & $\begin{array}{l}\text { Reliability } \\
\text { (Cronbach's } \\
\text { alpha) }\end{array}$ & $\begin{array}{l}\text { Prior experience, } \\
\text { perceptions, and } \\
\text { expectations }\end{array}$ \\
\hline
\end{tabular}


Table I (Continued)

\begin{tabular}{|c|c|c|c|c|c|c|}
\hline Study & Country & $\begin{array}{l}\text { Target } \\
\text { population }\end{array}$ & $\begin{array}{l}\text { Development } \\
\text { and validation of } \\
\text { instrument }\end{array}$ & Implementation & $\begin{array}{l}\text { Reliability of } \\
\text { instrument }\end{array}$ & $\begin{array}{l}\text { Dimensions } \\
\text { measured in the } \\
\text { scale }\end{array}$ \\
\hline Murshid, $2015^{32}$ & Saudi Arabia & $\begin{array}{l}\text { Health care } \\
\text { providers }\end{array}$ & $\begin{array}{l}\text { A validated } \\
\text { questionnaire from } \\
\text { another published } \\
\text { study was used. } \\
\text { Content validity was } \\
\text { done }\end{array}$ & $\begin{array}{l}\text { Self-administered } \\
\text { questionnaire }\end{array}$ & $\begin{array}{l}\text { Reliability } \\
\text { (Cronbach's } \\
\text { alpha) }\end{array}$ & $\begin{array}{l}\text { Knowledge and } \\
\text { experiences }\end{array}$ \\
\hline Tsai et al, $2007^{38}$ & $\begin{array}{l}\text { Taiwan, } \\
\text { ROC }\end{array}$ & Dentists & $\begin{array}{l}\text { Development was not } \\
\text { mentioned. Content } \\
\text { validity was done }\end{array}$ & $\begin{array}{l}\text { Mailed } \\
\text { questionnaire }\end{array}$ & $\begin{array}{l}\text { No reliability } \\
\text { test was done }\end{array}$ & $\begin{array}{l}\text { Opinions and } \\
\text { experiences }\end{array}$ \\
\hline $\begin{array}{l}\text { Moore et al, } \\
2009^{39}\end{array}$ & USA & Alumni & $\begin{array}{l}\text { Self-developed, pilot- } \\
\text { tested. Validation was } \\
\text { not mentioned }\end{array}$ & $\begin{array}{l}\text { Mailed } \\
\text { questionnaire }\end{array}$ & $\begin{array}{l}\text { Reliability was } \\
\text { not mentioned }\end{array}$ & $\begin{array}{l}\text { Education, perceived } \\
\text { preparedness, and } \\
\text { experience }\end{array}$ \\
\hline $\begin{array}{l}\text { Chávez et al, } \\
2011^{40}\end{array}$ & USA & Alumni & $\begin{array}{l}\text { Development and } \\
\text { validation were not } \\
\text { mentioned }\end{array}$ & $\begin{array}{l}\text { Mailed } \\
\text { questionnaire }\end{array}$ & $\begin{array}{l}\text { Reliability was } \\
\text { not mentioned }\end{array}$ & $\begin{array}{l}\text { Perceptions of } \\
\text { education }\end{array}$ \\
\hline $\begin{array}{l}\text { Wolff et al, } \\
2004^{41}\end{array}$ & USA & Dental student & $\begin{array}{l}\text { Previously developed } \\
\text { survey. Not } \\
\text { mentioned }\end{array}$ & $\begin{array}{l}\text { Self-administered } \\
\text { questionnaire }\end{array}$ & $\begin{array}{l}\text { Reliability was } \\
\text { not mentioned }\end{array}$ & $\begin{array}{l}\text { Didactic and clinical } \\
\text { preparation, attitudes, } \\
\text { comfort levels, and } \\
\text { experiences }\end{array}$ \\
\hline $\begin{array}{l}\text { Al-Abdulwahab } \\
\text { and Al-Gain } \\
2003^{42}\end{array}$ & Saudi Arabia & $\begin{array}{l}\text { Health care } \\
\text { professionals }\end{array}$ & $\begin{array}{l}\text { Validity previously } \\
\text { mentioned in another } \\
\text { study }\end{array}$ & $\begin{array}{l}\text { Self-administrative } \\
\text { questionnaire }\end{array}$ & $\begin{array}{l}\text { Reliability } \\
\text { previously } \\
\text { mentioned in } \\
\text { another study }\end{array}$ & Attitudes \\
\hline
\end{tabular}

Preparedness and willingness of dental care providers

One of the challenges regarding dental care for special needs patients is whether dental care students are sufficiently prepared to treat patients with special needs. ${ }^{16}$ The Commission on Dental Accreditation (CODA) ${ }^{17}$ establishes new standards for dental care and dental hygiene education programs to ensure clinical opportunities to prepare future dental professionals to provide high-quality dental care to patients with special needs, stating that "graduates must be competent in assessing the treatment needs of patients with special needs" (p. 25). Because this issue has an impact on the oral health quality of patients with special needs, many studies have pointed out dental students' lack of attempts to treat patients with special needs and have documented that the predoctoral curricula for treating patients with special needs are inadequate. ${ }^{9} 18$ Moreover, studies have documented that limited dental care providers offer to treat patients with special needs and there are few who are prepared to educate dental students to be more competent to treat these patients in the future. ${ }^{9}{ }^{19}$ Furthermore, the more experience dental students have with the patients with special needs, the more able and willing they are to handle these patients..$^{22}$ Finally, this highlights the importance of establishing high-quality dental education programs to prepare undergraduate dental students for and to increase their willingness to treat patients with special needs now and throughout their careers. ${ }^{23,24}$ Obviously, there are many issues that influence dental care providers' willingness and competence to treat patients with special needs. ${ }^{25}$ It may be valuable to better understand dental education programs with regard to the treatment of patients with special needs and the impact it has on dental care practitioners' willingness to treat this population. ${ }^{13}$

\section{Cost of health care service}

One of the major issues associated with the quality of clinical services provided to patients with special needs is the knowledge of the health care provider and his/her ability to deliver and prescribe effective treatment. ${ }^{28}$ The lack of preparedness due to inadequate education and training of dentists in treating patients with special needs can lead to the provision of ineffective treatment, which can bring about further complications of oral health problems, thereby increasing the cost burden.

Although oral health care is typically relatively inexpensive, it becomes costly when it is neglected due to the lack of timely access to dental care services. Dao et al pointed out that if patients with special needs have limited access to dental care 
due to the lack of preparedness of dental care providers, it will lead to more oral complications for these patients that will be costly to the government and patients. ${ }^{13}$ Thus, this issue needs to be addressed thoroughly in the Saudi community.

In terms of willingness to treat patients with special needs, Tsai et al showed that reimbursement of dentists will affect their willingness to treat disabled patients; dentists under reward programs will be more willing in contrast with dentists from teaching hospitals. Nevertheless, the study pointed out that dental students who participate in programs to treat patients with special needs have more willingness and competence to treat these patients in the future. ${ }^{11,20,21}$

\section{Scales measuring preparedness and willingness}

Several studies have been directed toward dental students and dental health care providers to measure the factors influencing their behaviors that may limit or improve the access of patients with special needs to dental clinics (Table 1). 1,3,7,13,16,19,22-24,26-30 These studies attempted to measure the preparedness, $9,13,26,27$ experience, ${ }^{19,22,23,26,27}$ knowledge ${ }^{3}$ attitudes, ${ }^{13,26,29}$ and perceptions $^{7,24,31}$ of the dental care providers in regard to treating patients with special needs. The studies were directed at different target populations, where some targeted decision makers at dental teaching institutions, ${ }^{1,3,27}$ while others targeted clinical dental care providers ${ }^{29-32}$ and some studies targeted alumni and/or current students. ${ }^{7,13,19,22-24,26,28}$

Some of the reviewed scales were self-developed by the authors, ${ }^{16,23,26,27}$ while others adapted scales from the literature, ${ }^{22,29,30,32}$ and most of the reviewed studies did not mention the development of their scales.

Most of the reviewed studies either did not mention vali-

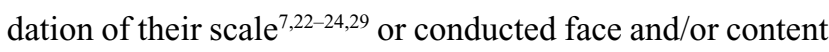
validity. ${ }^{16,26-28,32}$ Only one study mentioned conducting construct validity by conducting inter-item correlation. ${ }^{19}$ None of the reviewed scales were fully validated.

\section{Conclusion}

The Iron Triangle of Health Care ${ }^{8}$ has been used as a framework for this study, where the following three major aspects are the core of any health care system: access to health care, the quality of health care, and the cost.

Patients with special needs are likely to experience poor oral health and have limited access to dental care services. This leads to an increase in oral health disease of patients with special needs, and if it is not managed, it will be costly to the government and patients themselves. Equitable and timely health care are two of the six domains of quality health care identified by the Institute of Medicine. ${ }^{33}$ There were limited data in Saudi dental literature describing the effect of dental care providers' training and willingness regarding treating individuals with special needs. Therefore, it is important to fill this gap of knowledge by studying dental care providers' perceptions of treating patients with special needs and the issues affecting their treatment in Saudi Arabia.

\section{Disclosure}

The authors report no conflicts of interest in this work.

\section{References}

1. Holder M, Waldman HB, Hood H. Preparing health professionals to provide care to individuals with disabilities. Int J Oral Sci. 2009;1(2):66-71.

2. Ettinger RL, Chalmers J, Frenkel H. Dentistry for persons with special needs: how should it be recognized? J Dent Educ. 2004;68(8):803-806.

3. Ahmad MS, Razak IA, Borromeo GL. Undergraduate education in special needs dentistry in Malaysian and Australian dental schools. J Dent Educ. 2014;78(8):1154-1161.

4. Gallagher JE, Fiske J. Special Care Dentistry: a professional challenge. Br Dent J. 2007;202(10):619-629.

5. Waldman H, Al-Nowaiser A, Hamed M, Perlman S. Dentistry for individuals with special needs in Saudi Arabia: a commentary. J Disab Oral Health. 2010;11(2):57-60.

6. Steinberg BJ. Issues and challenges in special care dentistry. $J$ Dent Educ. 2005;69(3):323-324.

7. Kleinert HL, Sanders C, Mink J, et al. Improving student dentist competencies and perception of difficulty in delivering care to children with developmental disabilities using a virtual patient module. J Dent Educ. 2007;71(2):279-86.

8. Kissick W. Medicine' Dilemmas: Infinite Needs versus Finite Resources. New Haven: Yale University Press; 1994.

9. Fenton SJ, Hood H, Holder M, May PB, Mouradian WE. The American Academy of Developmental Medicine and Dentistry: eliminating health disparities for individuals with mental retardation and other developmental disabilities. J Dent Educ. 2003;67(12):1337-1344.

10. Waldman HB, Fenton SJ, Perlman SP, Cinotti DA. Preparing dental graduates to provide care to individuals with special needs. $J$ Dent Educ. 2005;69(2):249-254.

11. Dentistry AAoP. Management of Dental Patients with Special Health Care Needs. 2016. Available from: http://www.aapd.org/media/Policies_Guidelines/BP_SHCN.pdf. Accessed October 23, 2018.

12. Adyanthaya A, Sreelakshmi N, Ismail S, Raheema M. Barriers to dental care for children with special needs: General dentists' perception in Kerala, India. J Indian Soc Pedod Prev Dent. 2017;35(3):216-222.

13. Dao LP, Zwetchkenbaum S, Inglehart MR. General dentists and special needs patients: does dental education matter? J Dent Educ. 2005;69(10):1107-1115.

14. Campbell JT, Mccaslin FC. Evaluation of a dental training program for care of the handicapped. Spec Care Dentist. 1983;3(3):100, 102-107.

15. Adams T. Dentistry and medical dominance. Soc Sci Med. 1999;48(3): 407-420.

16. Clemetson JC, Jones DL, Lacy ES, Hale D, Bolin KA. Preparing dental students to treat patients with special needs: changes in predoctoral education after the revised accreditation standard. J Dent Educ. 2012;76(11):1457-1465.

17. Accreditation CoD. Accreditation Standards for Dental Education Programs. Chicago: American Dental Association; 2004.

18. Waldman HB, Perlman SP. Preparing to meet the dental needs of individuals with disabilities. J Dent Educ. 2002;66(1):82-85.

19. Delucia LM, Davis EL. Dental students' attitudes toward the care of individuals with intellectual disabilities: relationship between instruction and experience. J Dent Educ. 2009;73(4):445-453. 
20. Grantham EV, Block MJ. Effect of extramural experiences on dental students' attitudes. J Dent Educ. 1983;47(10):681-684.

21. Block MJ, Walken JW. Effect of an extraumural program on student attitudes toward dental care for the mentally retarded. J Dent Educ. 1980;44(3):158-161.

22. WolffAJ, Waldman HB, Milano M, Perlman SP. Dental students' experiences with and attitudes toward people with mental retardation. $J \mathrm{Am}$ Dent Assoc. 2004;135(3):353-357.

23. Moore PA, Boynes SG, Cuddy MA, Giovannitti JA, Zovko J. Educational experiences and preparedness in dental anesthesia: five-year outcome assessment and conclusions. $J$ Dent Educ. 2009;73(12):1379-1386.

24. Chávez EM, Subar PE, Miles J, Wong A, Labarre EE, Glassman P. Perceptions of predoctoral dental education and practice patterns in special care dentistry. J Dent Educ. 2011;75(6):726-732.

25. Wilder RS, O'Donnell JA, Barry JM, et al. Is dentistry at risk? A case for interprofessional education. J Dent Educ. 2008;72(11):1231-1237.

26. Alkahtani ZM, Stark PC, Loo CY, Wright WG, Morgan JP. Saudi and U.S. dental student attitudes toward treating individuals with developmental disabilities. J Dent Educ. 2014;78(8):1145-1153.

27. Vainio L, Krause M, Inglehart MR. Patients with special needs: dental students' educational experiences, attitudes, and behavior. $J$ Dent Educ. 2011;75(1):13-22.

28. Tsai WC, Kung PT, Chiang HH, Chang WC. Changes and factors associated with dentists' willingness to treat patients with severe disabilities. Health Policy. 2007;83(2-3):363-374.

29. Al-Abdulwahab SS, Al-Gain SI. Attitudes of Saudi Arabian health care professionals towards people with physical disabilities. Asia Pacific Disab Rehabil J. 2003;14(1):63-70.

30. Derbi HA, Borromeo GL. The Perception of Special Needs Dentistry amongst General Dentists within Western Australia, Australia. J Gerontol Geriatr Res. 2016;5(4):2.

31. Casamassimo PS, Seale NS, Ruehs K. General dentists' perceptions of educational and treatment issues affecting access to care for children with special health care needs. J Dent Educ. 2004;68(1):23-28.
32. Murshid EZ. Dental knowledge of educators and healthcare providers working with children with autism spectrum disorders. Saudi Med J. 2015;36(12):1477-1485.

33. (IOM) IoM. Crossing the Quality Chasm: A New Health System for the 21st Century. Washington (DC): National Academy Press; 2001.

34. Vainio L, Krause M, Inglehart MR. Patients with special needs: dental students' educational experiences, attitudes, and behavior. J Dent Educ. 2011;75(1):13-22.

35. Ahmad MS, Razak IA, Borromeo GL. Undergraduate education in special needs dentistry in Malaysian and Australian dental schools. $J$ Dent Educ. 2014;78(8):1154-1161.

36. Kleinert HL, Sanders C, Mink J, et al. Improving student dentist competencies and perception of difficulty in delivering care to children with developmental disabilities using a virtual patient module. J Dent Educ. 2007;71(2):279-286.

37. Delucia LM, Davis EL. Dental students' attitudes toward the care of individuals with intellectual disabilities: relationship between instruction and experience. J Dent Educ. 2009;73(4):445-453.

38. Tsai WC, Kung PT, Chiang HH, Chang WC. Changes and factors associated with dentists' willingness to treat patients with severe disabilities. Health Policy. 2007;83(2-3):363-374.

39. Moore PA, Boynes SG, Cuddy MA, Giovannitti JA, Zovko J. Educational experiences and preparedness in dental anesthesia: five-year outcome assessment and conclusions. $J$ Dent Educ. 2009;73(12):1379-1386.

40. Chávez EM, Subar PE, Miles J, Wong A, Labarre EE, Glassman P. Perceptions of predoctoral dental education and practice patterns in special care dentistry. J Dent Educ. 2011;75(6):726-732.

41. Wolff AJ, Waldman HB, Milano M, Perlman SP. Dental students' experiences with and attitudes toward people with mental retardation. $J \mathrm{Am}$ Dent Assoc. 2004;135(3):353-357.

42. Al-Abdulwahab SS, Al-Gain SI. Attitudes of Saudi Arabian health care professionals towards people with physical disabilities. Asia Pacific Disab Rehabil J. 2003;14(1):63-70.
Clinical, Cosmetic and Investigational Dentistry

\section{Publish your work in this journal}

Clinical, Cosmetic and Investigational Dentistry is an international, peer-reviewed, open access, online journal focusing on the latest clinical and experimental research in dentistry with specific emphasis on cosmetic interventions. Innovative developments in dental materials, techniques and devices that improve outcomes and patient satisfac-

\section{Dovepress}

tion and preference will be highlighted. The manuscript management system is completely online and includes a very quick and fair peerreview system, which is all easy to use. Visit http://www.dovepress. com/testimonials.php to read real quotes from published authors. 